\title{
General practitioners' level of knowledge about their rights and criminal liabilities according to legislation in Turkey
}

\author{
BAKI DERHEM ${ }^{1, A-G}$, MEHMET UNGAN ${ }^{2, A}$ \\ ${ }^{1}$ Sivas Public Health Directorate, Yildizeli Family Health Center, Yildizeli, Sivas, Turkey \\ ${ }^{2}$ Ankara University Faculty of Medicine Department of Family Medicine, Ankara, Turkey
}

A - Study Design, B - Data Collection, C - Statistical Analysis, D - Data Interpretation, E - Manuscript Preparation, F - Literature Search, G - Funds Collection

Summary Background. To know legal regulations and to comply with them while providing health care is indispensable for physicians to work in a proper way. Ignorance of the criminal laws may not be an excuse according to Turkish Criminal Code. There is an obligation for physicians to know the law, as well as all citizens. Physicians should possess the scope of competences regarding medicolegal regulations at least.

Objectives. The aim of this study is to investigate the knowledge and behaviors of GPs regarding their rights, criminal liabilities and common rules of law that are regulated by legislation. We also aimed to determine how the answers were influenced by sociodemographic factors, educational status of participants and if the participants received any punishment.

Material and methods. A total number of 381 physicians working at primary health care services located in Ankara were interviewed face-to-face. We used a 38-item questionnaire that was developed according to current legislation. The collected data was analyzed using SPSS software (Version 11.5). The chi-square test was used in order to compare knowledge-based questions with sociodemographic factors. The Mann-Whitney $U$ test was used for assessing whether the number of correct answers differs with socio-demographic factors or not. A $p$-value of 0.05 was considered statistically significant.

Results. 21.8 percent of the participants were FM specialists, and $78.2 \%$ of them were GPs. The mean age of physicians was $46.9 \pm 7.6$. The median score for correct responses in 18 knowledge-based questions was 8 (min-max: 3-14). In comparison with the working experience with correct answers, there was a statistically significant difference between 1-5 years of experience and 11-15 years and $\geq 16$ years $(p<0.001)$. There was a significant difference in correct answers between the two groups, which were separated according to whether or not they received punishment as a result of a legal investigation. In our study, the doctors who have taken education about physician's rights and criminal liabilities before had a higher number of correct answer than those who have not taken $(p<0.001)$.

Conclusions. As a result of our survey, we determined that our physicians have insufficient levels of knowledge about medico-legal issues. The findings reveal the requirement for comprehensive education about a doctor's rights and liabilities during residency or via in-service trainings. The importance of the situation should be investigated by further studies and constructive steps should be initiated as soon as possible.

Key words: medical law, medicolegal, family physicians, doctor's rights.

Derhem B, Ungan M. General practitioners' level of knowledge about their rights and criminal liabilities according to legislation in Turkey. Fam Med Prim Care Rev 2017; 19(4): 357-360, doi: https://doi.org/10.5114/fmpcr.2017.70804.

\section{Background}

To know legal regulations and to comply with them while providing health care is indispensable for physicians to work in a proper way. Ignorance of the criminal laws may not be an excuse according to Turkish Criminal Code [1]. There is an obligation for physicians to know the law, as well as all citizens. Physicians should possess the scope of competences regarding medicolegal regulations at least [2].

Even if initial information about "Patient Rights" is based upon the ancient times (Hippocrates), it has begun to become popular as a sub-title of the concept of "Human Rights" following the publication of the "Universal Declaration of Human Rights". The first international regulation concerning this issue was the "World Medical Association of Lisbon on the Rights of the Patient", which was published in 1981, and "The European Consultation on the Rights of Patients", held in Amsterdam in 1994, followed. Patient rights are identified with the "Patient Rights By-law", which was effectuated in 1998 in Turkey and which is based on international conventions and increasing human rights [3]. Concerning patient rights, various educational activities and symposiums are coordinated, and the issue of pa- tient rights is continuously improving. On the other hand, working conditions, rights and the criminal liabilities of physicians are disorganizedly taking part in whole legislation, there isn't any clear and qualified regulation yet.

The number of studies which evaluate a physician's level of knowledge about legal regulations are limited. A large majority of the performed studies have been realized in the field of Gynecology and Obstetrics and Neurosurgery, as they are frequently faced with medicolegal matters [4]. Almost all of search results such as "physicians' knowledge of medical law", "physicians' knowledge of medicolegal issues" or "physicians' knowledge of legal regulations" are related to the examination of a doctor's level of knowledge about patient rights and informed consent [5-7].

Patient and physician rights are integral parts of the whole. The purpose of patient rights is to ensure that doctors work better. The purpose of physician rights is to make sure that physicians do their job in a more favorable environment while improving the condition of patients' health. Thus, improving the patients' health is the underlying purpose of the patient and physician rights. Therefore, determination and demarcation of physician rights is important for patient rights. Patients also have a new awareness of their rights throughout the world [8]. This situation results in the doctor being more afraid of making 
mistakes and loss of their objective perspectives. Defensive medicine is defined as the ordering of tests, procedures and visits or the avoidance of high-risk patients or procedures, primarily to reduce exposure to malpractice liability. Moreover, to avoid lawsuits, non-evidence-based procedures are frequently used [9].

Linton suggested that if physicians had more knowledge of the law, they would have less anxiety and perhaps practice less defensive medicine, and this decrease in the practice of defensive medicine could lead to a decrease in the cost of health care without decreasing the quality of care [10].

In professional literature, there is not enough data about physician rights and criminal liabilities. Moreover, we cannot find any study concerning the knowledge of family physicians who are working in primary care.

\section{Objectives}

The aim of this study is to investigate the knowledge and behaviors of GPs regarding their rights, criminal liabilities and common rules of law. Furthermore, the study was aimed to determine how socio-demographic factors influence the level of knowledge.

\section{Material and methods}

\section{Methods}

Study design. A descriptive survey study was designed to assess physicians' knowledge levels.

Study setting. The survey was carried out between July 2015 to September 2015. The study involved 381 family physicians who were working at Family Health Centers (FHC) providing primary health care in Ankara. The FHCs were selected randomly. All physicians were asked to participate, and the volunteers were included in the study. Physicians were interviewed face-to-face and information on identity was not requested.

\section{Materials}

We used a 38-item questionnaire that was developed according to current legislation. The questionnaire contained 18 knowledge-based questions, of which 7 questions investigate physician's rights, 7 questions investigate criminal liabilities, and 4 questions investigate common rules of law. The demographic section contained factors related to the topic: age, gender, experience, medico-legal education. Furthermore, we asked if they have had a legal investigation due to their profession and if they have received any punishment due to this.

The first 20 demographic questions were named "Part-1", the second 18 multiple-choice questions for knowledge levels were named "Part-2". A score of " 1 " was given for each correct answer in "Part-2", and a score of " 0 " was given for wrong answers. We then noted the total score at the end of the survey.

\section{Statistical analyses}

To summarize "Part-1", frequencies and percentages were used. The total number of correct answers did not have normal distribution, as determined by the Shapiro-Wilk test $(p<0.001)$, and thus the Mann-Whitney $U$ test was used for assessing whether the number of correct answers differed according to socio-demographic factors or not. The confidence interval was set to $95 \%$, and a $p$-value of $<0.05$ was considered significant. The data was analyzed using SPSS 11.5 for Windows.

\section{Permissions and ethics}

Firstly, we got permission from the Ankara University Faculty of Medicine Ethical Committee of Clinical Research and then the Turkish Public Health Institution. After permission was granted, we began the study.

\section{Results}

Three hundred eighty-one (381) family physicians working in Ankara participated in our study. The mean age of participants was $46.9 \pm 7.6$, and $54.3 \%(n=207)$ of the participants were male. Family physicians were working as civil servants.

Given the total duration of the physician's occupation, we found that 16 years and over is the maximum (79.5\%), followed by $11-15$ years $(12.1 \%)$. The mean hours of a physician's daily practice time was $8.04 \pm 0.2$ hours, and the mean number of patients per day was $52.5 \pm 13.2$.

$44.1 \%(n=168)$ of the participants stated they had a legal investigation 1 to 3 times due to their profession. $12.1 \%(n=46)$ of them stated 3 times or more. Of the 214 people who had at least 1 legal investigation, $52.3 \%(n=112)$ were penalized (no one has received imprisonment) and $47.7 \%(n=102)$ were not penalized. Amongst the doctors who were penalized, $62.5 \%$ ( $n=$ 70) of them had taken only "Warning penalty", $10 \%(n=12)$ had taken only "Administrative fine", $12 \%(n=14)$ had taken only "Reprimand". Besides, $12 \%(n=14)$ of penalized physicians had taken both warning penalty and administrative fine and $1.5 \%$ $(n=2)$ had taken all of them.

$27 \%(n=103)$ of the physicians noted they had taken an education about physicians' rights and liabilities during faculty of medicine and $28.9 \%(n=110)$ of physicians had taken during in-service training. On the other hand $31.5 \%(n=120)$ of physicians stated they had taken an education about patient rights during faculty of medicine and $46.5 \%(n=177)$ of them states they had taken during in-service training.

Only $10.8 \%(41)$ of the participants stated that "malpractice" did not lead them to practice defensive medicine.

According to Turkish regulations, doctors have the right to refuse patients in some situations. We asked the doctors about the following situations (Table 1 ).

Table 1. Knowledge of rights regarding refusing patients

\begin{tabular}{|l|l|l|l|}
\hline & $\begin{array}{l}\text { Yes } \\
n(\%)\end{array}$ & $\begin{array}{l}\text { No } \\
n(\%)\end{array}$ & $\begin{array}{l}\text { Total } \\
n(\%)\end{array}$ \\
\hline $\begin{array}{l}\text { Can the family physician } \\
\text { refuse his/her patient's } \\
\text { treatment for any per- } \\
\text { sonal reason? }\end{array}$ & $112(29.4)$ & $269(70.6)$ & $381(100)$ \\
\hline $\begin{array}{l}\text { If the patient doesn't } \\
\text { accept your consultation } \\
\text { request, can the doctor } \\
\text { cease treatment? }\end{array}$ & $158(41.5)$ & $223(58.5)$ & $381(100)$ \\
\hline $\begin{array}{l}\text { Can the family physician } \\
\text { refuse his/her patient's } \\
\text { treatment if he/she } \\
\text { predicts their own health } \\
\text { will come into danger? }\end{array}$ & $218(57.2)$ & $163(42.8)$ & $381(100)$ \\
\hline
\end{tabular}

We asked the question "Do family physicians have the freedom to choose treatment if there are different ways?", and $12.6 \%(48)$ of the physicians gave the answer "I explain all treatment methods to the patients and tell them which one I wish to apply". 42.2\% (161) answered "I explain all treatment methods to the patients and tell them to choose one". $45.2 \%$ (172) answered "I choose my way without any explanation".

The Expertise Regulation in Medicine states that "the daily limit of patients is 20 ; if there are more than 20 patients, the doctor has the right to demand extra doctors for patients". We asked about this regulation, and $17 \%$ (68) of participants gave the answer "20", and the highest response rate (28\%) was "unlimited".

We asked the question: "If your treatment doesn't result in healing, is there a criminal liability for you?", and almost the exact amount of $(87.4 \%(333))$ participants gave the answer "No".

We also tried to evaluate family physicians' knowledge of criminal liabilities according to the "Turkish Criminal Code", 
"Civil Servant Law" and "Turkish Deontology Regulation". The personal information which patients tell doctor is secret. We asked GPs: "To whom can doctors give the patients' secrets?". $32.8 \%$ (125) of the participants gave the correct answer (to nobody - according to article 4 of the Medical Deontology Regulation), and in the following question, we asked: "If the patient is dead, can you divulge his/her personal data to anybody?". 74\% (282) of the participant gave the answer: "To nobody".

The article 210 of the Turkish Criminal Code is "Any physician, dentist, pharmacist, mid-wife, nurse or other health personnel who issues false document is punished with imprisonment from three months to one year...". Only $24.9 \%$ (95) of GPs correctly answered the question: "What is the appropriate penalty for doctors who regulates false document (rest reports, drug reports... etc.) according to Turkish Criminal Code?". Similarly, only $19.4 \%$ (74) of GPs correctly answered the question: "What is the appropriate penalty for doctors who aren't insured with Mandatory Malpractice Insurance?".

The median score of knowledge-based questions was 8 (min-max: 3-14). There was no significant difference between the number of correct answers of knowledge-based questions and gender $(p=0.246)$. In comparison with the total score and years of experience, there was a significant difference between $1-5$ years and $11-15$ years and $>16$ years $(p<0.001)$. There was no significant difference between the total score and being indicted before or not $(p=0.194)$, but there was a statistically significant difference between being penalized and the total score of correct answers $(p=0.003)$. Participants who had education about physician rights and liabilities had a higher score than others $(p<0.005)$ (Table 2 ).

\begin{tabular}{|c|c|c|c|}
\hline & & $\begin{array}{l}\text { Total score } \\
\text { of correct } \\
\text { answers }\end{array}$ & $p$ \\
\hline \multirow[t]{2}{*}{ Status } & FM Specialists m (SD) & $8.07( \pm 1.90)$ & \multirow[b]{2}{*}{$0.007 *$} \\
\hline & $\begin{array}{l}\text { General Practitioners } \\
\mathrm{m}(\mathrm{SD})\end{array}$ & $7.43( \pm 2.21)$ & \\
\hline \multirow[t]{2}{*}{ Gender } & male m (SD) & $7.72( \pm 2.32)$ & \multirow{2}{*}{0.246} \\
\hline & female $\mathrm{m}(\mathrm{SD})$ & $7.39( \pm 1.94)$ & \\
\hline \multirow{4}{*}{$\begin{array}{l}\text { Profession } \\
\text { experience }\end{array}$} & $1-5$ years $m(S D)$ & $10.14( \pm 1.61)$ & \multirow{4}{*}{$<0.001^{*}$} \\
\hline & $6-10$ years $m(S D)$ & $8.77( \pm 1.16)$ & \\
\hline & $11-15$ years $m(S D)$ & $7.52( \pm 1.68)$ & \\
\hline & $\geq 16$ years $m(S D)$ & $7.39( \pm 2.20)$ & \\
\hline \multirow[t]{2}{*}{ Punishment } & punished m (SD) & $8.18( \pm 2.20)$ & \multirow{2}{*}{$0.003 *$} \\
\hline & not punished m (SD) & $7.38( \pm 1.89)$ & \\
\hline \multirow{2}{*}{$\begin{array}{l}\text { Education } \\
\text { in service } \\
\text { training }\end{array}$} & educated m (SD) & $8.18( \pm 1.90)$ & \multirow[b]{2}{*}{$<0.001^{*}$} \\
\hline & not educated $\mathrm{m}$ (SD) & $7.32( \pm 2.21)$ & \\
\hline
\end{tabular}

*Significant at $p<0.05 ; \mathrm{m}-$ mean; SD - standard derivation.

\section{Discussion}

In general, a doctor is involved in a number of medical interventions for the person's inviolability and health while doing his/her profession. The purpose of the physician during these interventions is not to harm patients. On the contrary, the purpose is to improve their health condition. This goal forms the basis of all medical activities [2]. Thereby, it is not possible for a physician to knowingly and willingly harm his or her patient. The main problem in malpractice is negligence and lack of attention, as well as not knowing the necessary procedures [11].

Even if surgical branches are faced with malpractice lawsuits more in Turkey, increasing the patient's consciousness and awareness about "Patient Rights" contains a threat to GPs in the future. $46.5 \%$ ( $n=177)$ of the participants stated they have received education about patient rights during in-service training, and this supports national policies on the dominance of patient rights. Performing this study in central Ankara may be the reason for the high average age $(46.9 \pm 7.6)$.

In the survey study performed for Canadian Family Medicine residents by Saltstone et al., 22 (48.9\%) residents said they had taken a course on medical law at medical school, and $71.1 \%$ (32) said they had received some medical-legal education during their residency [8]. In our study, $27 \%(n=103)$ of the physicians stated they had education about physician rights and liabilities, and $31.5 \%(n=120)$ had education on patient rights during faculty of medicine.

The statistically significant difference between being penalized and the total score of correct answers $(p=0.003)$ is an important issue for think while there was no significant difference between total score and being indicted before or not $(p=$ 0.194). The median score of correct answers for "Part-2" was 8 (range 3 to 14 ) in our study. Saltstone et al. indicated that the mean score for correct medical legal responses was 8.6 (range 5 to 12 ) out of 16 [8].

In comparison with the total score and years of experience, there was a significant difference between 1-5 years and 11-15 years and $>16$ years $(p<0.001)$. Similarly, in the research in 2013 performed by Zajdel et al. among doctor of internal medicine in Poland, doctors with 10-20 years of experience had a statistically higher level of knowledge about medical law than more experienced doctors [2]. In another study performed in Bilaspur, practitioners having between $6-10$ years of experience were more aware, followed by $11-15$ years $(p=0.001)$ [4]. In our study, older doctors had a higher level of knowledge about the basic rules of law than younger doctors. Given these two conclusions, we can say there is an increasing level of knowledge about general rules of law with age, but about the occupational issues (medicolegal issues) youngers are better. Participants who had education about physician rights and liabilities had a higher score than others $(p<0.005)$. Obviously, this is not a surprising result.

A study performed by Ocaktan et al. in Ankara among all health providers working at 20 Family Health Centers and $3 \mathrm{Ma}-$ ternal-Child Health and Family Planning Centers positively assessed their knowledge of patient rights and their attitudes [12].

In another study performed by Topbaş et al. in the Karadeniz Technical University Faculty of Medicine, they applied a survey to evaluate the level of knowledge of patient rights amongst residents, and they found a mean score of 6.04 out of 10 and assessed their level of knowledge as "medium" [13]

Yurumez et al. [14] stated that at Afyon Kocatepe University, the residents' mean score about patient rights is 75 out of 100 points. In Turkey, the awareness of patient rights is acceptable, while the level of knowledge about physician rights is low. We believe that this is an important reason for the application of "Defensive Medicine".

\section{Limitations of the study}

Certain limitations of this study might affect the ability to generalize the results. First, due to the study being performed in the capital of Turkey, the mean age of the participants was higher in comparison to other cities $(46.9 \pm 7.6)$, and as the study results showed that older physicians have a slightly higher level of knowledge about medico-legal law.

Another limiting issue is the questionnaire, as we only asked one or two questions to assess each situation on a specific law. To measure physicians' knowledge reliably, many more questions on a specific subject would be required, necessitating the use of a much longer and more time-consuming survey. 


\section{Conclusions}

Primary care physicians may find themselves in some bad medicolegal situations because of their long-term relationships with patients and the breadth of their practice. The awareness of patients about their rights also leads physicians to practice defensive medicine.

Family doctors, who play an important role in the management of resources, must know both physician and patient rights well in order to avoid "defensive medicine" just as unnecessary laboratory tests, over-prescribings, more consultations and referrals to second care. This reveals the requirement of comprehensive education concerning a doctor's rights and liabilities during residency or via in-service trainings.

In professional literature, there is not enough study information to reveal the level of knowledge about medico-legal law among general practitioners. The importance of the situation should be investigated by further studies, and constructive steps should be initiated as soon as possible.

Source of funding: This work was funded by the authors' own resources. Conflict of interest: The authors declare no conflict of interests.

\section{References}

1. Turkish Criminal Code [cited 23.12.2016]. Available from URL: http://www.wipo.int/edocs/lexdocs/laws/en/tr/tr171en.pdf.

2. Zajdel J, Zajdel R, Kuna P. Knowledge of medical law amongst doctors of internal diseases. Int J Occup Med Environ Health 2013; 26(2): 242-256.

3. Regulation of Patient Rights [cited 13.12.2016]. Available from URL: http://www.saglik.gov.tr/TR,10461/hasta-haklari-yonetmeligi. html.

4. Haripriya A, Haripriya V. Knowledge about medical law and its negligence among doctors: a cross-sectional study. Int J Sci Res Pub/ 2014; 4(5): $1-3$.

5. Cong Y. Doctor-family-patient relationship: the Chinese paradigm of informed consent. J Med Philos 2004; 29(2): 149-178.

6. Rai JJ, Rajesh VA, Deepak D. Knowledge and awareness among interns and residents about medical law and negligence in a medical college in Vadodara - a questionnaire study. IOSR-JDMS 2013; 3(4): 32-38.

7. McCrary SV, Swanson JW, Perkins HS, et al. Treatment decisions for terminally ill patients: physicians legal defensiveness and knowledge of medical law. Law MED Health Care 1992; 20(4): 364-376.

8. Saltstone SP, Saltstone R, Rowe BH. Knowledge of medical-legal issues. Survey of Ontario family medicine residents. Can Fam Physician 1997; 43: 669-673.

9. Asher E, Greenberg-Dotan S, Halevy J, et al. Defensive medicine in Israel - a nationwide survey. PLoS One 2012; 7(8): e42613, doi: 10.1371/journal.pone.0042613.

10. Linton AL. The widening gulf between medicine and the law. CMAJ 1988; 139: 17-20.

11. Nash L, Walton M, Daly M, et al. GPs' concerns about medicolegal issues: how it affects their practice. Aust Fam Physician 2009; 38(1-2): 66-70.

12. Ocaktan E, Ayşe Y, Oya Ö. Abidinpaşa Sağlık Grup Başkanlığı Bölgesinde Çalışan Sağlık Personelinin Hasta Hakları Konusunda Bilgi ve Tutumları. Journal of Ank Univ Fac of Med 2004; 57(3): 129-137 (in Turkish).

13. Topbaş M, Özlü T, Çan G, et al. Hekimler Hasta Haklarını Ne Kadar Biliyorlar? Bir Tıp Fakültesindeki Asistan ve İntern Hekimlerin Bilgi Düzeyleri. Turkiye Klinikleri J Med Ethics 2005; 13(2): 81-85 (in Turkish).

14. Yurumez Y, Cevik T, Yavuz Y. Hasta Haklarini Biliyor muyuz? Akademik Acil Tip Dergisi 2010; 9(2): 67-71 (in Turkish).

Tables: 2

Figures: 0

References: 14

Received: 08.03.2017

Revised: 07.04.2017

Accepted: 12.06.2017

Adress for correspondence:

Baki Derhem, MD

Yildizeli Family Health Center

Atatürk Street

Yildizeli, Sivas

Turkey

Tel.: +905547932473

E-mail:dr.baki71@gmail.com 